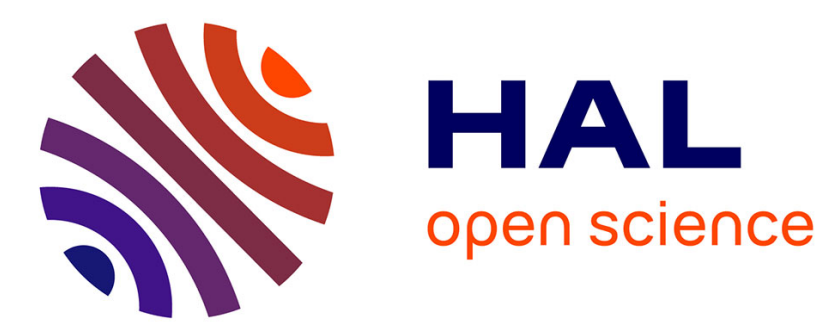

\title{
The Future of Financial Markets and Regulation: What Strategy for Europe?
}

Jean-Baptiste Gossé, Dominique Plihon

\section{To cite this version:}

Jean-Baptiste Gossé, Dominique Plihon. The Future of Financial Markets and Regulation: What Strategy for Europe?. 2011. hal-00613251

\section{HAL Id: hal-00613251 \\ https://hal.science/hal-00613251}

Preprint submitted on 3 Aug 2011

HAL is a multi-disciplinary open access archive for the deposit and dissemination of scientific research documents, whether they are published or not. The documents may come from teaching and research institutions in France or abroad, or from public or private research centers.
L'archive ouverte pluridisciplinaire HAL, est destinée au dépôt et à la diffusion de documents scientifiques de niveau recherche, publiés ou non, émanant des établissements d'enseignement et de recherche français ou étrangers, des laboratoires publics ou privés. 


\title{
The Future of Financial Markets and Regulation:
}

\section{What Strategy for Europe?}

\author{
Jean-Baptiste Gossé ${ }^{1}$
}

Dominique Plihon ${ }^{2}$

\begin{abstract}
This article provides insight into the future of financial markets and regulation in order to define what would be the best strategy for Europe. To preserve financial stability, Europe has to choose between financial opening and independently determining how to regulate finance. Among the five scenarios we defined, three achieve financial stability both inside and outside Europe. In terms of market efficiency, the multi-polar scenario is the best and the fragmentation scenario is the worst, since gains of integration depend on the size of the new capital market. Regarding sovereignty of regulation, fragmentation is the best scenario and the multi-polar scenario is the worst because it necessitates coordination at the global level which implies moving further away from respective national preferences. However, the more realistic option seems to be the regionalisation scenario: (i) this level of coordination seems much more realistic than the global one; (ii) the market should be of sufficient size to enjoy substantial benefits of integration. Nevertheless, the "European government" might gradually increase the degree of financial integration outside Europe in line with the degree of cooperation with the rest of the world.
\end{abstract}

Key words: Financial Stability, Supervision and Regulation, Financial Integration

JEL Classification: E44, F36, G18, G28

\footnotetext{
${ }^{1}$ CFAP, University of Cambridge. email: jg548@ cam.ac.uk.

${ }^{2}$ CEPN, Université Paris 13. email: plihon@univ-paris13.fr.

Corresponding author: Jean-Baptiste Gossé, Centre for Financial Analysis and Policy (CFAP), Cambridge Endowment for Research in Finance (CERF), Cambridge Judge Business School, Trumpington Street, Cambridge CB2 1AG.

The authors would like to thank Leonard Field, Robert Guttmann, Tarik Mouakil, Pascal Petit and the AUGUR project members for their helpful comments on an early draft.
} 


\section{Introduction}

The recent financial crisis, which is not over yet, has shown that finance matters a lot and exerts a powerful influence on the world economy. The increasing importance of finance, both private and public finance, is particularly true in Europe. Finance plays an essential role for the (mis)allocation of capital among sectors and countries. It is also a major factor of instability, both for the financial and the real sectors of the economy, at all levels: national, regional and international.

A priori, it seems difficult to forecast what will be the evolution of financial markets in the coming decades, not least because finance is fundamentally unstable! Nevertheless, it is crucial to define what could be the future of finance due to its central importance for the world and European economies.

Forecasting the evolution of finance is needed for regulation purposes: there is a need to adapt the rules to the transformation of financial markets in the future. This study is an attempt to analyze the wide array of possibilities in the future, as they range: (i) from a reform based on micro-prudential regulation to a strong state-controlled macro-prudential regulation; (ii) from regulation at a national level to regulation at a global level; and (iii) from strong capital controls between economic areas to strong financial integration.

The methodology of this study will consist in building contrasted scenarios in order to allow for strategic thinking about the evolution of finance up to 2030. The scenarios will be built around the strategies of the major actors, public and private, of the world economy and financial markets, including the interrelated role of financial regulation and financial innovation. This study will also focus on the role of Europe as concerns financial markets and the impact of finance on Europe in 2030.

The study is composed of three sections. The first section provides a description of the spontaneous trends of financial markets, with a focus on major players. Section 2 builds on the evolution of financial system depending on the different types of regulations implemented in the future decades. Finally, section 3 provides a panorama of five alternative scenarios based on different assumptions as to the strategies and the role of major players. These scenarios provide a framework for the analysis of the future of Europe in the world economy. 


\section{I-The spontaneous tendency of financial markets}

In this part, we define the spontaneous tendency of finance in order to pinpoint what could be the future strategies of operators, the future locations of financial centres, the most promising markets, and the new major players.

\section{Future strategies of financial operators}

The financial operators' view is determinant in shaping future finance, since they will take strategic decisions inside banks and financial institutions. According to European bank managers and financial executives ${ }^{3}$, the main challenges are (i) the improvement of risk management, (ii) the adaptation to changing regulation, (iii) the intensification of price competition, (iv) the concentration of financial markets, and (v) the standardization of financial operations to facilitate automation, replacing workers with machines. Thus, financial institutions will try to increase their size and to reduce costs of financial transactions to deal with stronger competition in more globalised financial markets. Furthermore, while financial operators seem to have realized at least partially the shortcomings of their own risk management in the past, they worry now more about new regulatory constraints. To put it in a different way, they would prefer to deal with financial instability at the firm level rather than be closely controlled by state supervisors and regulatory authorities.

\section{Future locations of financial centres}

The future locations of financial centres will probably be rebalanced with the emergence of deeper markets in the emerging market economies. First, the development of Islamic finance could help centres to thrive in the Middle East and in Asia ${ }^{4}$. Secondly, if commodities became major safe havens for investors, some new centres in emerging countries - which produce them - could play a growing role ${ }^{5}$. Thirdly, the opening of financial markets in the emerging countries would undoubtedly change the situation greatly. For example, in 2010 China decided to make the Renminbi convertible for non-residents, paving the way for Honk Kong to become the most important financial centre in Asia.

\footnotetext{
${ }^{3}$ For more details, see Engstler and Welsch (2008), KPMG, (2008), and Ernst \& Young, (2009).

${ }^{4}$ According to International Financial Services London (2010), the countries which could benefit from the development of Islamic finance are: Iran, Saudi Arabia, Malaysia, Kuwait, UAE and Bahrain.

${ }^{5}$ The BM\&F Bovespa (Sao Paolo) or the National Commodity and Derivatives Exchange (Mumbai), which grew rapidly in the last years, may have a stronger role in the future. We can also mention the brand new Dubai Multi Commodities Centre.
} 


\section{Promising markets}

It is rather difficult to identify promising markets for the next 20 years. There are some emerging new markets such as ethical and green finance which could be destined to play an important role in the future, but it is too early to assess their future importance. This depends crucially on future innovations, which are closely linked to regulation. According to both specialists and practitioners, the strategic markets should be derivatives. Otherwise, over-thecounter markets could grow fast to avoid organized markets which could be much more regulated in the future. But this evolution may be stopped by new regulation, under study today, about the obligation of all actors on OTC to register with clearinghouses.

\section{Players}

The major players of financial markets will be both public and private entities. In the first place, the growth in the number of sovereign wealth funds ${ }^{6}$, which prefer riskier investments, could increase the exposure of government-controlled investments. Whereas central bank purchases of safe assets reduced the global interest rate in the 2000s, the growth of risky investments made by sovereign funds may lead to an increase in asset prices. On At the same time, private actors such as hedge funds and private equity are called upon to play an increasing role. It is difficult to define what would be their activities in the future, because those depend on the regulatory reforms that will be put in place. Nevertheless, speculative activities of hedge funds imply important systemic risks and may create contagion effects in the banking system. Public actors - regulators, states, central banks, and international organizations - are also bound to play an important role if the instability of financial markets is to be persistent. It may be that in some emerging countries - such as China - public authorities will play a dominant role, while the influence of private players is more important in countries where the market economy is more developed, as is the case in the US and in Europe. At the international level, civil society (meaning non-governmental organizations defending the general interest) is also bound to play an increasing role. International organizations, such as the IMF, may also have a growing influence, depending on the nature of the likely reforms of the international monetary system.

\footnotetext{
${ }^{6}$ Most of the sovereign wealth funds are in China, Russia and the OPEC countries which are major exporters of, respectively, manufactured goods and oil.
} 


\section{Financial innovation vs. regulation}

The development of financial innovation has been motivated for a long time by the desire to avoid taxes or government regulation. We can therefore expect that new regulatory constraints will be circumvented by financial innovations to come. We can distinguish two ways of avoiding regulatory constraints. On the one hand, financial operators can escape regulators by transferring their capital to offshore financial centres with a high degree of financial secrecy. On the other hand, institutions can create some new financial products and develop a "shadow banking system" or a "shadow financial market" in order to steer clear of regulation and supervision.

\section{II-Tools to regulate financial markets}

\section{The two dimensions of financial regulation: micro- and macro-prudential regulations}

The role of prudential regulation is to prevent bank failures and financial crises. The reason for preventing financial crises is that the costs to society are more important than crises in other sectors and exceed the private cost to individual financial institutions. Prudential regulation aims at internalizing these externalities in the behaviour of such institutions. Prudential regulation has two dimensions: micro-prudential and macro-prudential. Microprudential regulation concerns itself with the stability of individual entities and the protection of clients of these institutions. Macro-prudential regulation concerns itself with the stability of the financial system as a whole. Micro-prudential regulation consists of such measures as (i) the certification of those working in the financial sector; (ii) rules on what assets can be held by whom; (iii) how instruments are listed, traded, sold and reported; (iv) measures of the value and riskiness of assets. The Basel Committee on bank supervision has played a major role in defining the rules and instruments of micro-prudential regulation. One of the main tools put forward by the Basel Committee is that of capital adequacy requirements.

Until recently, the Basel approach rested on the principle that the purpose of regulation is to ensure the soundness of individual institutions against the risk of loss on their assets. The Basel Committee doctrine was based on the false assumption that actions enhancing the soundness of a particular institution should also promote overall stability. However, ensuring the safety of each individual institution is not a sufficient condition for the soundness of the system as a whole. It is possible, indeed often likely, that attempts by individual institutions to remain solvent can push the system to collapse. The recent crisis was caused by banks 
transferring risky toxic assets to other financial unregulated financial institutions such as hedge funds. One of the major causes of the crisis has been the deficit of macro-prudential regulation.

Micro-prudential regulation examines the responses of an individual bank to exogenous risks. By definition, it does not incorporate endogenous risk. It also ignores the systemic importance of individual institutions as defined by their size, the degree of leverage they use, and their interconnectedness with the rest of the system. This is why we need to complement microprudential regulation with macro-prudential regulation. The macro-prudential approach to regulation considers the systemic implications of the collective behaviour of banks.

A critical feature of macro-prudence and systemic stability is the heterogeneity of the financial system. Homogeneity - everyone selling or buying at the same time - undermines the system. Invariably, market participants start off being heterogeneous but a number of factors - such as the use of similar techniques of risk measurement by banks - drive them to homogeneity. In this regard systemic risk is endogenous, and macro-prudential regulation is about identifying those endogenous processes that turn heterogeneity into homogeneity.

There is a growing consensus that the most important manifestation of market failure in banking and financial markets is pro-cyclicality. According to this view, the purpose of macro-regulation is to act as countervailing force to the pro-cyclical behaviour of banks which is based on their underestimation of risks in a boom and their overestimation of risks in the subsequent collapse. This shift in risk perception from "too low" to "too high" is an essential problem. The purpose of macro-prudential regulation is to moderate financial cycles by narrowing this gap in forcing banks to improve their measurement of risks in boom and bust.

A critical part of micro-prudential regulation in the last decade was the increasing use of market prices in valuation and risk assessment. This was done in the name of transparency, risk-sensitivity and prudence, but what it achieved was increasing homogeneity and cyclicality of market behaviour, hence also increased systemic fragility. Micro-prudential behaviour can thus endogenously create macro-prudential risks.

Counter-cyclical bank regulation can be introduced through banks' dynamic provisions systems, linking provisioning to the credit cycle. This technique has already been used in Spain and Portugal. Such a system requires higher provisions when credit grows more than historical average and lower provisioning in slumps. An alternative approach for counter- 
cyclical bank regulation is via capital requirements. Basel III guidelines presented in September 2010 propose making bank capital charges counter-cyclical.

Micro and macro-prudential regulation differ in their needed professionalism. Microprudential regulation should be carried out by banking and financial market supervisors, whereas macro-prudential regulation should be put under the responsibility of central banks. Central banks should have to monitor credit expansion which is a major channel of bubbles and financial crises. Such instruments as loan-to-value ratios and progressive compulsory reserves on bank credit may be used by central banks to reduce credit cycles.

Not all banks are alike. Regulation should acknowledge that some banks are systemically important. Tighter supervision of the latter banks needs to be implemented. By the same token, international cooperation is required for the regulation and supervision of banks which operate in several countries.

In short, the subprime crisis has shown that the existing framework of banking regulation was insufficiently macro-prudential. A reform of financial and banking regulation is under way to introduce new instruments, and to achieve a new balance between micro- and macroprudential regulations. This is illustrated by the new Basel III guidelines presented in September 2010 or the reforms implemented in 2011 in the European Union along the lines proposed by the Larosière Report.

\section{Financial regulation at the international level}

At the international level, the regulator has three main objectives which are not necessarily compatible: (i) financial stability, (ii) independence of regulatory policy, (iii) financial integration.

Financial stability seems to be the most obvious target. Since the last crisis a fairly clear consensus has emerged among the G20 central bankers (Banque de France, 2011). They agree on the need for enhanced supervision of the financial sector - especially for systemically important financial institution (SIFI) - and greater coordination of national policies in order to ensure financial stability internationally. One can note two interesting nuances among central bankers of emerging countries. They expect a change in the International Monetary System (IMS), which would imply more competition against the dollar, and better regulation of 
speculative capital flows, by nature more volatile, since those have a particularly destabilizing effect on emerging markets.

The independence of regulatory policy may appear desirable, because it allows each country to regulate its financial market according to national preferences. For example, following the example of Germany, other countries might wish to ban short sales or opt for more stringent prudential standards for systemically important actors (e.g. hedge funds). Indeed, preferences in the regulation of financial markets are quite heterogeneous in the world. On one side, Europeans seem willing to put in place a regulatory regime based on a strong coercive power of the authorities. On the other side, the United States appear more directed towards a system focused on market-based insurance mechanisms (Goodhart, 2010).

For many years much of the economic literature has been arguing in favour of a greater degree of financial integration which is defined as better access to foreign capital markets for investors. Financial integration is supposed to have several advantages. Firstly, it enables a more efficient capital allocation, because savers benefit from a wider choice in their investment decisions and potentially have access to more lucrative investments. Secondly, the deregulation of national markets allows investors to diversify the risk of their portfolios more effectively by holding assets that are less correlated due to the fact that they are issued in countries with different economic characteristics.

The second point, however, raises two questions. The first question concerns the impact of globalization on national circumstances. In recent decades traditional barriers to trade in goods and services and to capital flows have eroded and economies have become increasingly interdependent. When a shock occurs, it is felt throughout the system via fewer commercial opportunities, lower investment incomes, and devaluations of foreign assets. The second question is that of the consequences of greater financial integration on the resilience of financial markets. Indeed, there are good grounds for considering that breaking down barriers between national financial markets increases the global systemic risk. Thus, the reduction of portfolio risk expected from the international diversification is not so obvious, since financial integration would cause an increase in the risk to which all assets are exposed. Thus, the deepening of financial integration is beneficial only if systemic risk is reduced by an appropriate regulation at the global level. 
To sum up, the efficiency of micro-prudential and macro-prudential measures depends on the capacity to control international financial markets. We can identify three main objectives of regulation at the international level. First, authorities try to reach a high degree of financial integration to allow a better allocation of capital and to permit a better diversification of risks. Second, governments want to improve financial stability, including the need to avoid international arbitrage between financial centres and their regulations (e.g. tax havens). Third, decision makers wish to maintain the independence of the national regulatory system in order to decide how financial activities should be regulated (e.g. limitations on short selling). These three objectives cannot be combined.

\section{Figure 1. The incompatibility triangle of financial objectives}

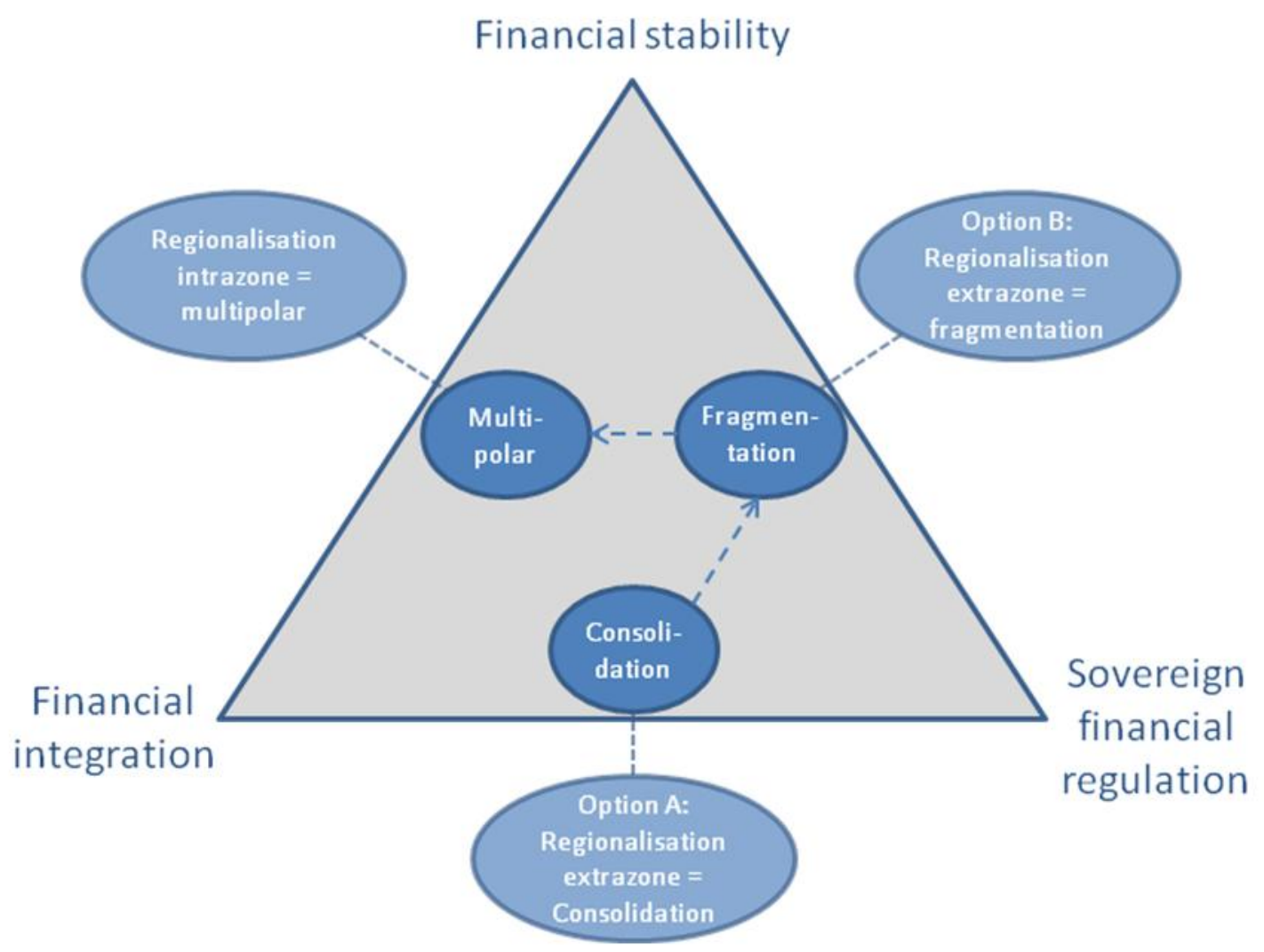

Note: in this figure, we indicated the scenarios described in the third part.

The trilemma in financial regulation at the international level can be represented by a triangle with one of the objectives at each vertex. The regulator has to leave aside one of them. As financial stability is currently the first priority, authorities must either reduce financial 
integration or accept to reinforce international governance ${ }^{7}$. Thus, it is necessary to adapt the scale of international regulation to the scale of risk caused by greater financial integration at the global level.

In the context of open capital markets, it is impossible for a single nation-state to define an effective regulation of finance. Financial institutions will seek the least restrictive supervision system so as to avoid compliance with the standards set by the regulator ${ }^{8}$. Thus, even the most powerful prudential arsenal at the national level will be rendered inefficient by the opening-up of financial markets which permits investors to direct capital flows to the less regulated financial centres. G20 measures targeting tax havens seem inadequate. The list provided by the OECD is based primarily on criteria of transparency and exchange of information that are neither able to prevent offshore financial centres operating nor even neutralize the off-balance sheet investment vehicles ${ }^{9}$.

\section{III-Five scenarios}

After describing the spontaneous tendencies of finance and the tools available to regulate it, we will now discuss the effect of different regulatory policies on the natural evolution of markets. The issue is to describe the impact they could have on the world, according to the configuration chosen, and to determine what would be the best strategy for Europe. To do this, we define five scenarios ${ }^{10}$ that are distinguished by the leading actors who have the power to impose their strategies to the world. Alternatively, we define five groups distinguished by decision makers: Chimerica (United States and China), multinational corporations, nation-states, regional blocs, and supranational authorities.

\section{Chimerica: United States-China}

In this scenario, current trends continue, assuming that on the economic and financial levels the United States and China are in a position to impose their decisions, since none of the major players opposes them. On the one hand, the United States pursues a domestic demandled growth strategy. The Fed conducts an accommodative monetary policy, and fiscal policy

\footnotetext{
${ }^{7}$ See Aglietta (2011).

${ }^{8}$ For further details about the inadequacy between international financial markets and institutions, and national supervision and crisis management, see (Goodhart and Lastra, 2010).

${ }^{9}$ See on this point, the protest of Josef Pröll, the Austrian Minister of Finance (Vanessa Houlder, «Ports in a storm », Financial Times, November 17, 2009.

${ }^{10}$ See Table 1 for details on scenarios.
} 
is occasionally used to cover shortfalls in demand. On the other hand, China favours an export-led growth and continues to accumulate foreign exchange reserves - in dollars and, increasingly, in other currencies - to perform a slow and gradual revaluation of the Renminbi. In this way, the price competitiveness of China is maintained and the transition to domestic demand-led growth takes place smoothly.

In this context, commodity export revenues will continue to grow. Sovereign wealth funds in commodity-exporting countries acquire an increasing amount of assets in developed countries, and very soon a steady income replaces commodity revenues. China and commodity-producing countries, which hold a large share of their assets in U.S. currency, maintain their peg to the US dollar which remains the international reference currency.

Europe and the rest of the world are subjected to the growth strategies of other actors. The euro appreciates, because the U.S. and Chinese growth strategies cause a sharp increase in the supply of dollar assets relative to other currencies. European growth is slowed by the rise of prices expressed in euros. As debt sustainability depends on interest rates and on the growth rates of the GNP, GIIPS ${ }^{11}$ should find more and more difficult to meet interest payments. The euro area experiences increasingly strong tensions. Germany pursues its strategy of wage moderation, while the relative unit labour cost continues to grow in GIIPS (except in Spain and Ireland where it has been decreasing since $2008^{12}$ ). Since the Eurozone becomes weaker, the European influence on the global economy decreases rapidly. Moreover, as China and commodity-exporting countries diversify their exchange reserves in favour of Euros, Europe should pay increasingly high interests to these countries, which reduces GNP.

\section{Consolidation: multinational corporations (minimum state)}

We continue another important trend in recent decades: the declining power of states, matched at the same time by the growing influence of multinational corporations. We assume that large firms are becoming increasingly powerful. Thus, they can take advantage of competition between states that seek to become more attractive, particularly in terms of taxation, regulation, or confidentiality. Thus, multinationals have power to bypass regulation and supervision that governments try to establish. Investors will flock to financial markets

\footnotetext{
${ }^{11}$ Greece, Italy, Ireland, Portugal and Spain.

${ }^{12}$ See De Grauwe (2010), Figure 4.
} 
with soft regulation at the expense of those trying to impose measures that reduce the competitiveness of firms, but are essential to the establishment of financial stability.

Financial institutions are given free rein to develop their business globally. Financial industry becomes more concentrated, because players seek to reach the minimum size needed to be internationally competitive. Meanwhile, stock exchange markets continue to merge. After the creation of Euronext ${ }^{13}$ in 2000 and its merger with the New York Stock Exchange to create the NYSE Euronext group, a new merger could take place with Deutsche Börse. Thus, if the integration process taking place today in Europe and North America continues, it could well lead to the creation of a single global financial market that would improve liquidity.

Governments tend to establish the least stringent regulatory standards possible - what is often termed the "race to the bottom" - and prefer self-regulation to attract large financial institutions that generate higher incomes. Within this oligopolistic global financial market, the trend towards automation of financial transactions continues without being too heavily constrained by regulators. The development of high-frequency trading generates an increase in gross trading volume, while net trading volume stagnates. We observe recurrent financial panics which can result from decisions of large operators and from the spread of automated trade execution ${ }^{14}$. Finally, the reinforcement of global financial integration increases systemic risk, but there is no supranational authority to regulate this supranational market.

The few measures that have been taken to improve macro-prudential regulation are rapidly circumvented, because governments feel the need to woo financial institutions which make high profits. At the same time, the concentration of finance implies an increase in the number of systemically important financial institutions (SIFI) and hence aggravates financial instability. In such a context, it is likely that financial crises and stock-market panics will become more frequent. This scenario could also lead to the fragmentation of the eurozone, which would result from a sudden stop in capital inflows to GIIPS.

\footnotetext{
${ }^{13}$ The group was founded in 2000 with originally Amsterdam Stock Exchange, Brussels Stock Exchange and Paris Bourse. Then, LIFFE joined them in 2001 and the Bolsa de Valores de Lisboa e Porto (BVLP) in 2002.

${ }^{14}$ The stock market crash of 6 May 2010 provides an interesting example of such a financial panic. On this day, the main US financial indexes fell by $10 \%$ within 15 minutes, before returning to their previous level. For further information on the role played by automated trading strategies, see the report of the CFTC and SEC (2010) on that so-called "flash crash."
} 


\section{Fragmentation: Nation-state (economic nationalism)}

The negative effects of globalization experienced by workers create a feeling of economic patriotism. Most economies in Europe and elsewhere prefer to adopt purely national economic governance and strictly control international capital flows. The globalized financial and economic space is divided to correspond to the social and political space. Fragmentation is a major concern of the private sector which fears a return to a strong state. Ernst \& Young (2009) notes, moreover, a buzz on the word «protectionism» at the 2009 Davos Conference and that the fight against it is a priority for most decision makers.

The financial markets are becoming more localized, and the regulation is country-specific. In some countries, the banking system may even be nationalized to closely regulate market activities. The retreat into protectionism also involves the establishment of exchange controls and the setting up of currency-undervaluation strategies which may further destabilize the foreign exchange market. In such a context, there exist major arbitrage opportunities for those with the ability to execute trades across borders.

The euro-zone is fragmented, and each member-state returns to its previous national currency. This scenario is far from being impossible, if one looks at the nicknames used to refer to the indebted economies. The group of countries consisting of Greece, Ireland, Italy, Portugal and Spain are often referred as PIIGS, GIPSI or "club med" by the economic press, in academia, and among bond analysts. These quite offensive nicknames stigmatize the lack of seriousness of indebted countries and reflect a deep resentment among North European countries against their Southern neighbors.

The abandonment of the euro would have serious consequences on Europe. The intra-EU trade would be reduced because of the instability of prices in foreign European currencies and increase in transaction costs. European currencies become vulnerable again to speculative attacks and to currency crisis. The borrowing costs rise in South European countries, whereas German growth substantially slows down because of the appreciation of the Deutsche mark which becomes the main safe haven for investors. Finally, neither the North nor the South European countries seems to have an interest in returning to national monetary and exchangerate policies. 


\section{Regionalisation: Regional integration}

In this case, the negative effects of financial globalization generate a different reaction of the national states: instead of reducing the economic space at the national level, they decide to create regional economic spaces. At the same time, political power is organized at the regional scale to meet the size of the economic space. Regional-states put in place a common financial regulation at the bloc level. We can also imagine the emergence of regional initiatives to counterbalance the power of governments and the influence of firms. Thus, a group of European elected officials launched a call" to "organize the creation of a nongovernmental organization capable of developing a counter-expertise on activities carried out on financial markets by the major operators". The goal of the "finance watch" project is to compete with the private lobbies which contributed to the engagement in riskier lending activities (Igan et al., 2009).

In this scenario financial regulation is region-specific. The regional governments control capital flows to avoid regulatory arbitrage between regions. The blocs can be constituted on the basis of existing agreements. Beside the European Union, we could imagine that NAFTA, ASEAN, MERCOSUR, the CIS or the Arab League would move towards a stronger financial integration. The fragmentation of financial markets requires the financial institutions to adopt a different strategy in each bloc in order to adapt to region-specific characteristics.

The eurozone enlarges to increase its weight in the world economy and the size of its domestic market. In fact, the wider the financial integration area and the more unified the regulation system are, the better the capital allocation and the diversification of portfolio risk will be. The full range of economic policy is put in place at the European level, beyond just monetary or fiscal policy. Europe benefits from advantages of financial integration at the continental level and can establish a financial regulation compatible with its systemic risk aversion, perhaps even creating a currency transaction tax. Afterwards, the "European government" might increase financial integration with the rest of the world in line with the degree of cooperation of regional blocs on prudential supervision and mutual surveillance of their banking systems.

\footnotetext{
${ }^{15}$ See the website of Finance Watch: http://www.callforfinancewatch.org/.
} 


\section{Multi-polar: global integration and supranational regulation}

The multi-polar scenario implies both a strong intervention capacity of governments and massive participation of civil society in the functioning of financial markets. First, governments of major world economies reach an agreement (e.g. at the level of G20, or an enlarged G20) on financial regulation and create the necessary institutions to enforce these common rules. Thus, political power is established at the scale of financial globalization with suitable supranational institutions capable of addressing the need for proactive global systemic risk management. Indeed, the cooperation of governments on a sufficiently binding regulation and the capability of supranational institutions to prevent the creation of offshore financial centres - as well as to limit other shadow transactions - are prerequisites for stabilizing financial markets.

Second, this scenario necessitates the emergence of a counterbalancing force besides governments' and multinational corporations' powers. If there is already a world social forum for civil society - which is the answer to Davos' World economic forum for corporations and to G20 summits for governments - this third force is not yet sufficiently organized to respond to the challenges of globalization, especially at the financial level.

There are, however, some interesting citizens' initiatives aimed at rebalancing globalization. On the one hand, Obstfeld and Rogoff (2009) claim that "the interaction among the Fed's monetary stance, global real interest rates, credit market distortions, and financial innovation created the toxic mix of conditions making the U.S. the epicentre of the global financial crisis." Thus, it seems more than necessary to create a civil society organization - i.e. the equivalent of the European "Finance Watch" at the global scale - that would keep an eye on financial authorities and institutions in order to avoid the repetition of such a disaster.

On the other hand, civil society could also put in place payment systems in addition to traditional banking. Lietaer (2008) argues that the development of local monies would deal with the problem of crises in increasing the resilience of the economic system, even if it would reduce the efficiency of the monetary system. Therefore, the question of monetary creation is sensitive, since the excess of liquidity - which means a creation of liquidity beyond the credit absorption capacity of the US economy - contributed to the subprime crisis. Ethical finance is an interesting alternative for investors wishing to devote their savings to progressively managed firms which respect the environment, comply with the international 
labour code, and refrain from speculative activities. The development of such finance could have stabilizing effects on markets.

To summarize, in this scenario we assume a combined success of governments and civil society to rebalance the financial globalization process. On the government side, success implies renouncing national preferences. Nation-states must adopt a similar regime of financial regulation with common rules in order to avoid regulatory arbitrage. This means the end of tax havens that would render ineffective the attempts to regulate at the global level. On the civil-society side, counterbalancing powers must be created to oppose the lobbies of financial institutions and to watch the developments of financial markets. Under these conditions Europe and the rest of the world could fully enjoy the benefits of financial globalization, yielding a more efficient allocation of capital and better distribution of risk.

\section{Conclusions}

The aim of this article was to provide insight into the future of financial markets and regulation in order to define what would be the best strategy for Europe. The main objectives of financial regulators should be stability and market efficiency. However, favourite methods to achieve stability can be rather different from country to country and may depend on national preferences or institutional tradition.

We have shown that it was difficult to combine financial stability with both financial integration and sovereign financial regulation. This implies that Europe has to choose between financial opening and independently determining how to regulate finance. The options are summed up in Table 2. Three of the five scenarios achieve financial stability both inside and outside Europe. In terms of market efficiency, the multi-polar scenario is the best and the fragmentation scenario is the worst, since gains of integration depend on the size of the new capital market. Regarding sovereignty of regulation, fragmentation is the best scenario and the multi-polar scenario is the worst because it necessitates coordination at the global level which implies moving further away from respective national preferences.

Finally, even if the multi-polar scenario is the first best solution, the more realistic option seems to be the regionalisation scenario. On the one hand, the regional level of coordination seems much more realistic than the global one, since the preferences are much more similar on that scale. On the other hand, it should be of sufficient size in order to enjoy substantial benefits of integration. However, it may be appropriate for the "European government" to 
gradually increase the degree of financial integration outside Europe in line with the degree of cooperation with the rest of the world. 


\section{References}

Aglietta M., (2011), "Déséquilibres globaux et transformation du système monétaire international", Confrontations Europe la revue, janvier-mars 2011.

Banque de France, (2011), “Global Imbalances and Financial Stability”, Financial Stability Review, $\mathrm{n}^{\circ} 15$, February 2011.

CFTC-SEC, (2010), Findings Regarding the Market Events of May 6, 2010, Report of the Staffs of the CFTC and SEC to the Joint Advisory Committee on Emerging Regulatory Issues, September 30, 2010.

De Grauwe P., (2010), “The Financial Crisis and the Future of the Eurozone”, BEEP briefing $n^{\circ} 21$, December 2010.

Engstler M. and R. Welsch, (2008), "Banks \& Future preparing for the Scenario 2015", The European Foresight Monitoring Network.

Ernst \& Young, (2009), "The Future of Finance: Driving business value through the performance of the Finance function".

Goodhart C., (2010), "The Role of Macro-Prudential Supervision", Presented at the Federal Reserve Bank of Atlanta 2010 Financial Markets Conference: Up from the Ashes: The Financial System after the Crisis, Atlanta, Georgia May 12, 2010.

Goodhart C. and R. Lastra, (2010), "Border Problems", Journal of International Economic Law, Volume 13, Number 3, 1 September 2010, pp. 705-718(14).

Igan D., P. Mishra and T. Tressel, (2009), "A fistful of dollars: lobbying and the financial crisis”, IMF working paper 09/287, Washington DC: IMF, Dec. 2009.

International Financial Services London, (2010), "Islamic Finance 2010”, IFSL Research, January 2010.

KPMG, (2008), "Finance of the Future: Looking forward to 2020", Financial Management Advisory.

Lietaer, B., (2008), Monnaies régionales : des nouvelles voies vers une prospérité durable, Charles Léopold Mayer, 2008. 
Obstfeld M. and K. Rogoff, (2009), "Global Imbalances and the Financial Crisis : Products of Common Causes“, CEPR discussion paper, n 7606.

World Economic Forum, (2009), "Financial System A Near-Term Outlook and Long-Term Scenarios", World Economic Forum USA Inc. 
Table 1. Presentation of the five scenarios

\begin{tabular}{|c|c|c|c|c|c|c|}
\hline & Bipolar & Consolidation & Fragmentation & Regionalisation & Multipolar \\
\hline \multicolumn{2}{|c|}{$\begin{array}{c}\text { Decision } \\
\text { makers }\end{array}$} & $\begin{array}{l}\text { USA-China } \\
\text { (Europe?) }\end{array}$ & $\begin{array}{l}\text { Big companies } \\
\text { (minimum state) }\end{array}$ & $\begin{array}{c}\text { Nation-state } \\
\text { (Economic nationalism) }\end{array}$ & Regional integration & Supranational \\
\hline \multirow{3}{*}{ 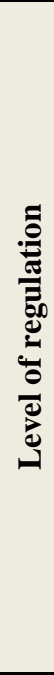 } & 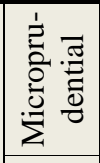 & Basel III & $\begin{array}{l}\text { Emphasis on microprudential } \\
\text { regulation (Autoregulation) }\end{array}$ & Country-specific & Region-specific & Basel III modified \\
\hline & 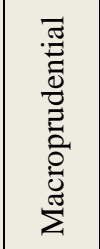 & $\begin{array}{l}\text { Some macroprudential } \\
\text { regulation and supervision. } \\
\text { Credit rating agencies are } \\
\text { more supervised but they are } \\
\text { still paid by the issuers } \\
\text { (conflict of interest). }\end{array}$ & $\begin{array}{l}\text { Macroprudential regulation is } \\
\text { circumvented by financial } \\
\text { innovations }\end{array}$ & Country-specific & Region-specific & $\begin{array}{l}\text { Supranational institution in } \\
\text { charge of macroprudential } \\
\text { regulation. Credit rating } \\
\text { agencies are closely } \\
\text { supervised and they are paid } \\
\text { by investors that they protect. }\end{array}$ \\
\hline & 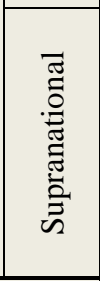 & $\begin{array}{l}\text { Minimum reform to improve } \\
\text { the transparency of tax havens }\end{array}$ & $\begin{array}{l}\text { The transparency is } \\
\text { insufficient and international } \\
\text { regulatory arbitrage continues }\end{array}$ & $\begin{array}{l}\text { No coordination of regulation } \\
\text { systems. Strong heterogeneity } \\
\text { of national preferences in } \\
\text { terms of financial regulation } \\
\text { (e.g. tax on financial } \\
\text { transactions, limitations on } \\
\text { short sellings) } \\
\end{array}$ & $\begin{array}{c}\text { Coordination inside regional } \\
\text { unions, but low coordination } \\
\text { between blocs }\end{array}$ & $\begin{array}{c}\text { Coordination at the global } \\
\text { level }\end{array}$ \\
\hline \multicolumn{2}{|c|}{$\sum_{i}^{\infty}$} & $\begin{array}{l}\text { IMS mostly based on dollar } \\
\text { with a more and more } \\
\text { important role for Yuan. Euro } \\
\text { remains a second class } \\
\text { currency. }\end{array}$ & $\begin{array}{c}\text { Domination of big banks and } \\
\text { accommodation by central } \\
\text { banks }\end{array}$ & $\begin{array}{l}\text { Three international moneys: } \\
\text { dollar, euro and yuan. }\end{array}$ & $\begin{array}{l}\text { A world money for } \\
\text { international transactions and } \\
\text { reserves (SDR or Bancor) }\end{array}$ & $\begin{array}{c}\text { Regional monetary zone } \\
\text { (Mercosur, euro area, } \\
\text { ASEAN, CIS, Arab league...) }\end{array}$ \\
\hline \multicolumn{2}{|c|}{ 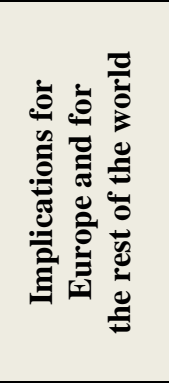 } & $\begin{array}{l}\text { Strong euro which adjust } \\
\text { global imbalances. Growing } \\
\text { tensions inside the euro area. }\end{array}$ & $\begin{array}{l}\text { Emergence of a world } \\
\text { financial markets open } 7 / 7 \& \\
\text { 24/24. Volatility of prices. } \\
\text { Persistent financial instability, } \\
\text { debt crisis and implosion of } \\
\text { the eurozone. }\end{array}$ & $\begin{array}{c}\text { Important arbitrage } \\
\text { opportunities between } \\
\text { countries. Implosion of the } \\
\text { euro area.Strong speculation } \\
\text { on North European countries } \\
\text { (Germany, Austria, } \\
\text { Netherlands...) and higher } \\
\text { cost of debt for GIIPS. } \\
\text { Reduction of trade intra } \\
\text { Europe. }\end{array}$ & $\begin{array}{l}\text { Development of a multipolar } \\
\text { network of financial centers } \\
\text { with some degree of } \\
\text { specialization Enlargment of } \\
\text { European Union to increase } \\
\text { the size of the domestic } \\
\text { economy. Strenthening of } \\
\text { political Europe. Stronger } \\
\text { economic and financial } \\
\text { integration in Europe. }\end{array}$ & $\begin{array}{l}\text { Regional financial integration } \\
\text { with differentiation of } \\
\text { financial systems, Growing } \\
\text { integration of European Union } \\
\text { with the world economy. } \\
\text { Reinforcement of the power } \\
\text { of global institutions (G20, } \\
\text { UN, IMF, WB, WTO...) } \\
\text { instead of European } \\
\text { institutions. }\end{array}$ \\
\hline
\end{tabular}


Table 2. Regulation policy at the international level

\begin{tabular}{|c|c|c|c|c|c|c|c|}
\cline { 3 - 7 } \multicolumn{1}{c|}{} & \multirow{2}{*}{ Decision makers } & \multicolumn{2}{c|}{$\begin{array}{c}\text { Financial } \\
\text { stability }\end{array}$} & \multicolumn{2}{c|}{$\begin{array}{c}\text { Financial } \\
\text { integration }\end{array}$} & \multicolumn{2}{c|}{$\begin{array}{c}\text { Heterogeneity of } \\
\text { national } \\
\text { regulations }\end{array}$} \\
\cline { 3 - 8 } & & $\begin{array}{c}\text { Inside the } \\
\text { euro area }\end{array}$ & $\begin{array}{c}\text { Outside the } \\
\text { euro area }\end{array}$ & $\begin{array}{c}\text { Inside the } \\
\text { euro area }\end{array}$ & $\begin{array}{c}\text { Outside the } \\
\text { euro area }\end{array}$ & $\begin{array}{c}\text { Inside the } \\
\text { euro area }\end{array}$ & $\begin{array}{c}\text { Outside the } \\
\text { euro area }\end{array}$ \\
\hline Bipolar & $\begin{array}{c}\text { USA-China } \\
\text { (Europe?) }\end{array}$ & + & - & + & + & - & + \\
\hline Fonsolidation & $\begin{array}{c}\text { Big companies } \\
\text { (minimum state) }\end{array}$ & - & - & + & + & + & + \\
\hline Regionalisation & $\begin{array}{c}\text { Nation-states } \\
\text { (Economic } \\
\text { nationalism) }\end{array}$ & + & + & - & - & + & + \\
\hline Regional unions & + & + & + & - & - & + \\
\hline Multipolar & $\begin{array}{c}\text { Supranational } \\
\text { institutions }\end{array}$ & + & + & + & + & - & - \\
\hline
\end{tabular}

